\title{
Pengembangan Komik Matematika dengan Metode Preview, Question, Read, Reflect, Recite, \& Review (PQ4R) Pada Materi Lingkaran Kelas VIII SMP
}

\author{
1Elsa Farapatana, ${ }^{2}$ Yunita Septriana Anwar, ${ }^{3}$ Abdillah \\ ${ }^{1,2,3}$ PendidikanMatematika, Universitas Muhammadiyah Mataram \\ 1elsa.ummat@gmail.com, ${ }^{2}$ na2 math@yahoo.com, ${ }^{3}$ ahmad fawwaz18@yahoo.co.id
}

\begin{tabular}{l} 
INFO ARTIKEL \\
\hline Riwayat Artikel: \\
Diterima: 07-03-2019 \\
Disetujui: 20-04-2019
\end{tabular}

\section{Kata Kunci:}

Media Komik;

Pembelajaran Matematika;

Metode PQ4R.

\section{Keywords:}

Comic Media;

Mathematic Learning;

PQ4R Method.

\begin{abstract}
ABSTRAK
Abstrak:Penelitian ini bertujuan untuk menghasilkan komik dengan metode pembelajaran PQ4R pada materi lingkaran kelas VIII SMP yang memiliki validitas, kepraktisan, dan efektifitas yang baik. Penelitian ini menggunakanmodel 4-D yaitu tahap pendefenisisan (define), tahap perancangan (design), dan tahap pengembangan (develop). Instrumen penelitian adalah lembar validasi komik, lembar kepraktisan komik dan lembar efektifitas komik. Hasil penelitian menunjukan bahwa (1) komik matematika dengan metode pembelajaran PQ4R termasuk dalam kategori valid dari aspek materi, bahasa, dan desain dengan skor rata-rata 4.01; (2) komiktersebuttermasuk dalam kategori praktis dengan skor rata-rata 4.14; (3) komiktersebut termasuk dalam kategori efektif dengan skor rata-rata 4.06.Kemudian pencapaian aktivitas meliputi (1) aktifitas dalam kegiatan belajar mengajar aktif dengan skor rata-rata aktivitas siswa 4.19; (2) respon siswa terhadap pembelajaran efektif dengan skor rata-rata respon siswa sebesar 4.27; (3) aktifitas dalam kegiatan belajar mengajar aktif dengan skor rata-rata aktivitas guru sebesar 4.42; dan (4) hasil belajar siswa efektif dengan skor rata-rata hasil belajar siswa sebesar 4,00 dan persentase rata-rata siswa yang mencapai nilai ketuntasan minimal 70 adalah $86 \%$.
\end{abstract}

Abstract:This study aims to produce comics with the PQ4R learning method on the material of the class VIII of junior high school that has good validity, practicality and effectiveness. This study uses a 4-D model, namely the stage of define, design, and develop. The research instruments were comic validation sheets, comic practicality sheets and comic effectiveness sheets. The results showed that (1) mathematical comics with the PQ4R learning method included in the valid category of material, language, and design aspects with an average score of 4.01; (2) the comic is included in the practical category with an average score of 4.14; (3) the comic is included in the effective category with an average score of 4.06. Then the achievement of activities includes (1) activities in active teaching and learning activities with an average score of student activity 4.19; (2) student responses to effective learning with students' average response scores of 4.27; (3) activities in active teaching and learning activities with an average score of teacher activity of 4.42; and (4) effective student learning outcomes with an average score of student learning outcomes of 4.00 and the average percentage of students who achieve a minimum completeness score of 70 is $86 \%$.

\section{d. 8 Crossref}

\section{$---------\diamond---------$}

\section{A. LATAR BELAKANG}

Matematika merupakan salah satu pelajaran yang sangat penting untuk diajarkan dalam setiap jenjang satuan pendidikan karena menjadikan menjadi dasar bagi perkembangan ilmu lain. Pelajaran matematika perlu diberikan kepada semua peserta didik mulai dari sekolah dasar untuk membekali peserta didik kemampuan berfikir logis, sistematis, kritis dan kreatif, serta kemampuan bekerja sama (Irawan, 2016), (Sariyem, 2016).

Prestasi pelajar Indonesia di bidang matematika, baik dalam kancah nasional maupun internasional, masih belum terbilang baik, hal ini ditandai dengan kualitas pendidikan di Indonesia sekarang ini tergolong rendah,dibuktikan dengan adanya data dari UNESCO dan Balitbang (2016) menyatakan bahwa peringkat matematika siswa sekolah 
menengah pertama indonesia berada di deretan 34 dari 38 negara. Hal ini terjadidisebabkan karena rendahnya sarana fisik, rendahnya kualitas guru, rendahnyakesejahteraan guru, rendahnya prestasi siswa, rendahnya kesempatan pemerataan pendidikan, dan mahalnya biaya pendidikan. Ada banyak faktor yang mempengaruhi keberhasilan siswa dalam belajar, salah satunya dipengaruhi cara penyajian materi oleh guru yang kurang menarik menyebabkan siswa menjadi bosan sehingga suasana belajar didalam kelas tidak menyenangkan (Sisworo, dkk, 2016), (Anggraini S, Patmanthara, \& Purnomo, 2016)

Penyajian materi hendaknya dikemas secara menarik sehingga dapat membangkitkan motivasi siswa dan mampu membuat siswa paham terhadap materi. Salah satu cara untuk menyajikan materi adalah dengan menggunakan media pembelajaran yang menarik dan mudah dipahami siswa yaitu dengan menggunakan komik. Komik memiliki 5 kelebihan jika dipakai dalam pembelajaran adalah memotivasi, visual, permanen, perantara dan populer (Gene Yang dalam Avriliyanti, 2013). Komik adalah bagian dari budaya populer karena sebelumnya proses pembelajaran hanya menggunakan buku teks biasa. Komik dapat menjadi salah satu media alternatif yang dapat digunakan untuk memotivasi dan memudahkan siswa dalam mempelajari dan memahami konsep matematika (Nida, Buchori, \& Murtianto, 2017), (Nurcikawati, 2018).

Selain itu berdasarkan masalah yang ditemukan peneliti di SMP Muhammadiyah Mataram yaitu rendahnya minat membaca siswa dikarenakan oleh media pembelajaran yang kurang menarik. Hal ini ditandai berdasarkan hasil wawancara yang dilakukan peneliti dengan siswa di SMP Muhammadiyah Mataram angkatan tahun pelajaran 2017/2018, diketahui siswa SMP Muhammadiyah Mataram tergolong rendah dalam minat membaca. Hal ini dikarenakan oleh media pembelajaran yang digunakan dalam proses pembelajaran kurang menarik ditandai dengan penyajian materi dalam media pembelajaran yang dibagikan guru terlalu rumit untuk difahami sehingga siswa merasa bosan dalam membaca. Selanjutnya diperoleh informasi bahwa banyak siswa suka membaca komik karena pada komik memuat gambar-gambar yang lucu, komik berisi percakapan yang memuat materi yang mudah dimengerti. Sedangkan hasil wawancara dari guru mata pelajaran matematika diperoleh informasi bahwa siswa pada saat proses pembelajaran sebagian besar dari mereka tidak memperhatikan guru yang menjelaskan hal ini disebabkan oleh media pembelajaran yang kurang memadai dan tidak pernah melakukan inovasi model pembelajaran yang terbilang kurang. Apabila guru dapat menyesuaikan rencana pembelajaran yang dapat memanfaatkan ketertarikan siswa dalam membaca komik diharapkan dapat tercipta pembelajaran yang menyenangkan sehingga prestasi belajar siswa dapat meningkat salah satu metode pembelajaran yang cocok untuk pengembangan media pembelajaran komik matematika adalah metode Preview, Question, Read, Reflect, Recite, Review (PQ4R) (Indrawati, Riyadi, \& Matsuri, 2014), (Zarnuji, 2017).

Metode PQ4R diawali dengan " $P$ " yang berarti Preview adalah siswa menemukan ide pokok bacaan, " $Q$ " yang berarti Question adalah siswa membuat pertanyaan sendiri, " $R$ " yang berarti Read yaitu tahapan siswa untuk membaca secara detail bacaan, " $R$ " berarti Reflect yaitu selama membaca tidak hanya menghafal namun juga mengingatnya, " $R$ " berarti Recite pada tahap ini siswa merenungkan kembali informasi yg dipelajari, dan yang terakhir " $R$ " adalah Review yaitu siswa membuat rangkuman dikembangkan oleh Thomas dan Robinson yang merupakan penyempurnaan dari metode Survey, Question, Read, Recite, dan Review(SQ3R)Survey berartimemeriksa atau meneliti atau mengidentifikasikan seluruh teks, Questio, berarti menyusun daftar pertanyaan yang relevan dengan teks, Read berarti membaca teks secara aktif untuk mencari jawaban atas pertanyaan-pertanyaan yang telah tersusun, Recite berarti menghafal setiap jawaban yang telah ditemukan, Review berarti meninjau ulang seluruh jawaban atas pertanyaan yang tersusun pada langkah kedua dan ketiga yang dicetuskan oleh Robinson (Wahyuni, 2012). Metode ini membantu siswa mengingat apa yang mereka baca, dan membantu proses belajar mengajar di kelas yang dilakukan dengan kegiatan membaca buku atau bahan ajar. Oleh sebab itu, metode PQ4R (Preview, Question, Read, Reflect, Recite, Review) menjadi salah satu alternatif yang digunakan dalam penelitian ini. Hingga akhirnya dalam proses pembelajara matematika para siswa tertarik untuk membaca dengan demikian mengakibatkan proses belajar siswa menyenangkan sehingga siswa yang biasanya tidak suka membaca buku teks akan tertarik apabila buku teksanya dipadukan dengan komik matematika dan akan merangsang siswa untuk belajar yang menyenangkan (Sidiq, 2017), (Pqr, Kurniati, \& Makur, 2018).

Berdasarkan wawancara dengan siswa dan guru SMP Muhammadiyah Mataram pada saat melakukan observasi di kelas VIII terhadap kegiatan pembelajaran, peneliti dapat menyimpulkan beberapa karakteristik siswa dalam pembelajaran matematika antara lain: (i) terdapat beberapa siswa yang tidak memperhatikan saat guru menjelaskan di depan kelas, (ii) siswa kurang suka belajar dengan buku yang telah disediakan guru, (iii) siswa yang mengerjakan tugas di papan tulis hanya siswa tertentu saja, (iv) sebagian siswa tidak suka menghafalkan rumus karena sulit mengingat materi pelajaran yang diberikan, (v) kebanyakan siswa 
bermukim di pondok dan karakteristik siswa adalah menengah ke bawah, (vi) sedangkan sebagian besar dari siswa bosan dengan proses pembelajaran di kelas yang masih menggunakan metode ceramah, yaitu guru menerangkan kemudian siswa mendengarkan, mencatat, dan mengerjakan tugas sesuai dengan perintah guru, hal ini menyebabkan proses pembelajaran di kelas tidak efektif dan prestasi siswa dalam pembelajaran kurang baik. Bahan ajar yang digunakan di dalam kelas, yaitu buku paket yang ditetapkan oleh sekolah yang diterbitkan Pusat Perbukuan Departemen Pendidikan Nasional.Buku paket yang digunakan di SMP Muhammadiyah Mataram membuat siswa jenuh dengan bahan bacaan yang kurang menarik.Berdasarkan beberapa karakteristik siswa tersebut dibutuhkan suatu bahan ajar untuk mengatasi permasalahan yang ada dan untuk membangkitkan ketertarikan siswa terhadap matematika.

Oleh karena itu, dikembangkan bahan ajar komik matematika berbasi metode PQ4R (Preview, Question, Read, Reflect, Recite, Review). Selain untuk memberikan ketertarikan siswa juga untuk merangsang siswa aktif daam kegiatan pembelajaran matematika khususnya pada materi lingkaran serta dapat meminimalisir peran guru dalam pembelajaran sehingga diharapkan siswa akan lebih tertarik dan aktif dalam pembelajaran matematika. Metode PQ4R (Preview, Question, Read, Reflect, Recite, Review) membantu siswa mengingat apa yang mereka baca, dan membantu proses belajar-mengajar di kelas yang dilakukan dengan kegiatan membaca buku atau bahan ajar (Amaliyah, 2019). Materi lingkaran dipilih karena berdasarkan latar belakang masalah materi ini sulit dipahami oleh siswa dan pada materi ini kebanyakan siswa kesulitan dalam menghitung dan mengoperasikan rumus pada soal matematika.

Selain itu, siswa belum mampu memrepresentasikan ide-ide matematika secara tertulis. Hal ini menunjukkan pemahaman tehadap materi pelajaran, siswa belum cukup baik dan menjadi daya tarik untuk diteliti (Aisha \& Ramadhani, 2017). Berdasarkan latar belakang masalah yang telah diuraikan, penggunaan media berbentuk komik dan metode PQ4R (Preview, Question, Read, Reflect, Recite, Review) menjadi salah satu alternatif dalam pembelajaran matematika yang diperkirakan dapat digunakan sebagai bahan ajar guru untuk mengajar siswa dalam belajar matematika. Selain itu, dapat memberikan pengaruh positif terhadap pembelajaran-pembelajaran matematika di sekolah. Oleh sebab itu, peneliti memilih judul "Pengembangan Komik Matematikadengan metode PQ4R (Preview, Question, Read, Reflect, Recite, Review)untuk Siswa SMP Muhammadiyah Kelas VIII Pada Pokok Bahasan Lingkaran".

\section{B. METODE PENELITIAN}

\section{Model Pengembangan}

Jenis penelitian yang akan dilakukan adalah penelitian pengembangan (research \& Development). Penelitian pengembangan adalah metode penelitian yang secara sengaja, sistematis untuk mencari temuan, memperbaiki, mengembangkan, menguji kefektifan produk, model/model tertentu yang lebih unggul, baru, efektif, efisien, dan produktif (Sugiyono, 2016).

\section{SubjekPenelitian}

Subjek penelitian pengembangan komik metode PQ4R ini adalah siswa-siswi kelas VIIIA SMP Muhammadiyah Mataram. Subjek penelitian ini terdiri dari 20 siswa kelas VIIIA dengan keanekaragaman kemampuan belajar yaitu tinggi, sedang, rendah. Jumlah siswa siswi Kelas VIII. Pemilihan siswa kelas VIIIA SMP Muhammadiyah Mataram sebagai sampel uji coba terbatasa dan uji lapangan (efektifitas) karena siswa kelas tersebut dalam proses pembelajaran hanya berpusat kepada guru sehingga aktivitas dan keaktifan siswa kurang optimal.

\section{Prosedur Pengembangan}

Prosedur dalam penelitian ini terbagi menjadi empat tahapan yakni: (a) tahap pendefinisian, (b) tahap perancangan, (c) tahap pengembangan, dan (d) tahap penyebaran

\section{Subjek Uji Coba}

Subjek uji coba pada uji coba terbatas terdiri dari 20siswa kelas VIIIA SMP Muhammadiyah Mataram.Sedangkan subjek uji coba pada uji coba lapangan terdiri dari 15 siswa kelas VIIIB SMP Muhammadiyah Mataram.

\section{Jenis Data}

Sesuai dengan tujuan penelitian pengembangan ini, data yang dikumpulkan terdiri dari dua macam yaitu:

a. Kualitatif, yaitu data berupa masukan atau saran dari tim ahli dan siswa pada saat uji coba produk baik uji coba terbatas maupun uji coba lapangan

b. Kuantitatif, yaitu data hasil angket tim ahli dan siswa pada saat uji coba produk baik uji coba terbatas maupun uji coba lapangan

\section{Instrumen Penelitian}

Instrumenyangdigunakan dalam penelitian iniadalah sebagai berikut:

a. Lembar ValidasiKomik

1) Lembar validasi materi

Validasi materi dilakukan untuk menilai kemampuan komik yang dirancang dalam mencapai kompetensi dasar dan indikator yang ditetapkan.

2) Lembar validasi Media

Validasi konstruksi dilakukan untuk menilai kesesuaian antara format dan bagian-bagian yang ditetapkan dengan komik yang dirancang. 
3) Lembar validasi bahasa

Validasi bahasa dilakukan untuk menilai ketepatan bahasa yang digunakan pada komik yang dirancang.

b. Lembar Kepraktisan Penggunaan komik. Instrumen ini berupa angket yang diberikan kepada guru dan siswa sebagai pengguna produk komik. Lembar ini digunakan untuk mengetahui kepraktisan dari rancangan komik yang telah valid. Lembar ini sebagai dasar untuk merevisi komik.

c. Lembar angket respon siswa. Instrument ini digunakan untuk mengetahui respon siswa terhadap komik untuk metode PQ4R pokok bahasan lingkaran yang dikembangkan.

d. Lembar angket aktivitas guru. Instrument ini digunakan untuk mendapatkan data tentang aktivitas guru dalam mengelola pembelajaran. Pengamatan ini dilakukan oleh dua orang pengamat selama proses pembelajaran berlangsung.

e. Lembar angket aktivitas siswa. Instrument ini digunakan untuk mendapatkan data tentang aktivitas siswa Selama proses pembelajaran berlangsung. Lembar aktivitas ini diisi oleh siswa.

f. Soal Evaluasi Kemampuan Pemahaman Konsep. Instrument ini digunakan untuk mendapatkan data mengenai evaluasi kemampuan siswa.

\section{Teknik Pengumpulan Data}

a. Data Validasi Ahli. Data validasi ahli diperoleh dari lembar validasi yang diisi oleh validator. Data hasil validasi ini kemudian dianalisis sebagai dasar untuk merevisi/ menyempurnakan komik yang akan digunakan dan dikembangkan.

b. Data Kepraktisan. Data kepraktisan komik diperoleh dari lembar Kepraktisan siswa yang terlibat dalam kegiatan pembelajaran menggunakan komik matematika dengan metode PQ4R.

c. Data Respon Siswa. Data respon siswa terhadap pembelajaran PQ4R diperoleh dengan menggunakan angket respon siswa diakhir proses pembelajaran.

d. Data aktivitas guru. Data aktivitas guru diperoleh dari angket yang diisi oleh pengamat. Data ini untuk mengetahui proses pembelajaran yang berlangsung.

e. Data aktivitas siswa

Data aktivitas siswa diperoleh dari angket yang diberikan kapada masing-masing siswa. Data ini untuk mengetahui aktivitas siswa selama proses pembelajaran yang berlangsung.

f. Data Hasil Belajar Siswa
Data ini diperoleh dari penilaian jawaban siswa sehingga dapat diketahui rata-rata nilai siswa. Data hasil belajar ini dikonversikan menjadi skor kriteria

\section{Teknik AnalisaData}

a. Analisis Kevalidan. Analisisdata yang dilakukan untuk mendapatkan komik untuk metode PQ4R yang valid, praktis, dan efektif adalah sebagai berikutAnalisis Kevalidan

Analisis data hasil validasi perangkat pembelajaran dilakukan dengan mencari rata-rata penilaian validator terhadap masing-masing perangkat pembelajaran. Rumus yang digunakan sebagai berikut :

$$
\bar{X}=\frac{\sum_{i=1}^{n} \overline{A_{i}}}{n}
$$

Keterangan :

$$
\begin{aligned}
& \bar{X}=\text { rata-rata } \\
& \overline{A_{i}}=\text { rata-rata pemilihan validitas } \\
& n=\text { banyaknya item penilaian }
\end{aligned}
$$

b. AnalisisKepraktisan

Analisis kepraktisan komik menggunakan lembar kepraktisan penggunaankomikolehgurudanlembarkeprak tisanpenggunaankomikoleh siswa. Rata-rata hasilpengisian lembar kepraktisan dicari denganrumus:

$$
\bar{M}_{p}=\frac{\sum_{i=1}^{n} \bar{P}_{i}}{n}
$$

Keterangan :

$\bar{P}=$ Skor rata-rata kepraktisan

$\bar{P}_{i}=$ Skor rata-rata kepraktisan ke-i

$\mathrm{n}$ = banyaknya siswa

c. Analisisefektivitas

Hasil penilaianoleh siswapadalembarangket aktivitas siswadengan rumus :

$$
\bar{A}_{\text {Siswa }}=\frac{\sum_{i=1}^{n} \bar{x}_{i}}{n}
$$

Ketarangan :

$\bar{A}_{\text {siswa }}=$ Nilai rata-rata aktivitas siswa

$\bar{x}_{i}=$ Nilai rata-rata aktivitas siswa ke-i

$\mathrm{n} \quad=$ banyak siswa.

\section{HASILDAN PEMBAHASAN}

Metode pengembangan perangkat pembelajaran ini merupakan penelitian pengembangan. Dalam penelitian ini mengembangkan beberapa produk yakni:

1. Perangkat Pembelajaran 
Perangkat pembelajaran matematika yang dikemabangkan meliputi Rencana Pelaksanaan Pembelajaran (RPP) dan komik matematika.

2. Instrumen Penelitian

Instrument penelitian yang dikembangkan meliputi lembar validasi RPP, lembar validasi komik, angket kepraktisan penggunaan komik, angket respon siswa terhadap perangkat dan proses pembelajaran, angket aktifitas siswa, angket aktifitas guru, soal evaluasi kemampuan pemahaman konsep.

Pada tahap definisi, pada bagian analisis awal-akhir diperoleh temuan bahwa (1) rendahnya minat membaca siswa dikarenakan buk ajar yang dibagikan guru kepada siswa kurang menarik, dan materi yang terdapat dalam buku ajar dirasakan terlalu rumit, sehingga berakibat pada rendahnya minat membaca siswa, (2) sekolah tidak menggunakan komik/buku ajar sebagai panduan bagi siswa sehingga proses menjagar oleh guru dirasakan lebih lama karena tidak memiliki pedoman, dan (3) proses KBM masih menggunakan metode ceramah yang membuat siswa merasa bosan dalam proses KBM.

Pada tahap desain, (1) peneliti mengumpulkan referensi yang terbaru di bidang pembelajaran matematika kelas VIII SMP, (2) mengumpulkan clip art dan animasi untuk pembuatan draf awal komik.

Berdasarkan hasil di atas, maka diperoleh draf awal komik terdiri dari beberapa bagian yakni:

1. Cerita Pembuka, yakni disajikan sebagai pengantar berkaitan dengan isi komik, dijelaskan permasalahan yang dihadapi seorang pengusaha yang kemudian dipecahkan melalui cerita lewat komik.

2. Kegiatan Siswa, meliputi tujuan pembelajaran, kegiatan pendahuluan, inti dan penutup tentang lingkaran.

3. Latihan Soal, berisi soal latihan yang harus dipecahkan oleh siswa.

4. Bagian Tambahan, meliputi cover, daftar isi, daftar pusataka.

Dari hasil penelitian diperoleh perangkat pembelajaran matematika berbasis metode pembelajaran $P Q 4 R$, sudah memenuhi tiga hal yaitu:

1. Perangkat pembelajaran valid berdasarkan penilaian validator.Dari hasil validasi oleh ahli diperoleh perangkat pembelajaran yang sesuai dengan kriteria valid. Rata-rata penilaian validator yaitu komik berdasarkan ahli materi 3,75(valid), komik berdasarkan ahli media 4,35 (sangat valid), dan komik berdasarkan ahlli bahasa 4,00 (valid) menunjukkan perangkat pembelajaran tersebut sudha baik dengan sedikit revisi.

2. Uji coba lapangan yang menghasilkan pembelajaran yang efektif, yaitu pretasi belajar siswa pada pembelajaran matematika materi lingkaran telah individual yang diinginkan dengan rata-rata nilai 75,23 .

3. Pelaksanaan pembelajaran dengan menggunakan komik matematika berbasis $P Q 4 R$ berjalan baik, meliputi respon siswa dan guru terhadap perangakat dan pelaksaan pembelajaran.

4. Respon siswa menunjukkan rata-rata respon siswa 4,27. Siswa senang, terhada komik berbasis $P Q 4 R$. sikap positif yang dimiliki siswa setelah pembelajaran didukung oleh beberapa faktor, antara lain :

a. Suasana belajar yang tidak tegang/kaku dan siswa dapat merasa bermain-main dan berekreasi.

b. komik yang digunakan telah dapat menarik perhatian siswa, karena disertai tanpilan yang menarik, memuat cerita yang membuat siswa tidak merasa jenuh dan disertai contoh soal untuk pemahaman siswa.

c. Siswa merasa memperoleh pengalaman belajar yang baru dan cukup berbeda dengan pengalaman belajar sebelumnya.

Proses pembelajaran di kelas menggunakan metode PQ4R berjalan dengan baik siswa antusias dalam proses pembelajaran sangat tinggi, karena selama proses pembelajaran sebelumnya hanya menggunakan satu metode. Hal ini menyebabkan siswa merasa bosan dalam proses KBM, peran siswa dalam pembelajaran di kelas menggunakan metode PQ4R sangat dominan dan berjalan lancer sesuai dengan yang diharapkan. Metode ini membimbing siswa untuk memahami konsep matematika yang terdapat materi pembelajaran. Pada proses ini diliputi oleh peran siswa dari awal proses KBM yaitu dengan siswa membaca sekilas bahan bacaan dan mencari ide pokok, sampai dengan membuat kesimpulan. Hal ini dapat mengasah kemampuan siswa dalam memahami konsep matematika dalam materi yang diajarkan, sehingga hasil belajar siswa mencapai persentase $86 \%$.

\section{SIMPULAN DAN SARAN}

Komik matematika dengan metode $P Q 4 R$ pada materi lingkaran ini telah memenuhi kriteria valid secara materi, bahasa, dan media. Sehingga komik yang dibuat oleh peneliti dapat dikategorikan sebagai komik yang valid, praktis dan efektif.

Berdasarkan pengalaman peneliti komik matematika Dengan metode PQ4R pada materi lingkaran penulis menyarankanUntuk mengembangkan komik selanjutnya, diperlukan kesesuaian isi silabus pembelajaran dengan tujuan, fungsi komik yang akan dikembangkan, proses validasi baik secara materi, bahasa dann desain dilakukan secara intensip agar menghasilkan kualitas komik yang baik dan Pengembangan komik untuk 
metode PQ4R ini hendaknya dikembangkan untuk materi matematika yang lainya serta digunakan sebagai referensi.

\section{REFERENSI}

Aisha, S., \& Ramadhani, N. (2017). Improving students' Reading comprehension achievement through preview, question, read, reflect, recite and review technique. Asian EFL Journal, 10, 60-64.

Amaliyah, E. (2019). Pengembangan Modul Matematika Berbasis Preview, Question, Read, Reflect, Recite, Review (PQ4R) Pada Matei Trigonometri Kelas Xi. JPM : Jurnal Pendidikan Matematika, 3(1), 01. https://doi.org/10.33474/jpm.v3i1.2603

Anggraini S, Patmanthara, S., \& Purnomo. (2016). Analisis faktor-faktor yang mempengaruhi hasil belajar kompetensi keahlian elektronika industri di SMKN 2 Singosari Malang. Prosiding Seminar Nasional Universitas Negeri Malang, 633-639.

Indrawati, T., Riyadi, \& Matsuri. (2014). Pengaruh Metode Pembelajaran Preview, Question, Read, Reflect, Recite, and Review (PQ4R) Terhadap Kemampuan Membaca Pemahaman. Jurnal Didaktika Dwija Indria, 2(9), 1-6.

Irawan, A. (2016). Peranan Kemampuan Numerik Dan Verbal Dalam Berpikir Kritis Matematika Pada Tingkat Sekolah Menengah Atas. AdMathEdu : Jurnal Ilmiah Pendidikan Matematika, Ilmu Matematika Dan Matematika Terapan, https://doi.org/10.12928/admathedu.v6i2.5443

Nida, I. K., Buchori, A., \& Murtianto, Y. H. (2017). Pengembangan Comic Math Dengan Pendekatan Etnomatematika Pada Meteri Kubus Dan Balok Di Smp. $\quad$ AKSIOMA, $3(1)$, https://doi.org/10.26877/aks.v8i1.1531

Nurcikawati, N. (2018). Rancang Bangun Media Pembelajaran Trigonometri Berbasis Multimedia Interaktif. SOSIOHUMANIORA: Jurnal Ilmiah Ilmu Sosial Dan Humaniora, 4(2). https://doi.org/10.30738/sosio.v4i2.2766

Pqr, R., Kurniati, K., \& Makur, A. P. (2018). Math Comics , Vectors, and the Strategy of Preview, Question,. Formatif: Jurnal Ilmiah Pendidikan MIPA, 8(3), 159174.

https://doi.org/http://dx.doi.org/10.30998/formatif .v8i3.2716 Math

Sariyem, S. (2016). Kemampuan Berpikir Kritis Dan Minat Baca Dengan Kemampuan Membaca Kritis Siswa Kelas Tinggi Sd Negeri Di Kabupaten Bogor. Jurnal Pendidikan Dasar, 7(2), 329. https://doi.org/10.21009/JPD.072.11

Sidiq, R. (2017). Penerapan Strategi Preview,Question, Read, Reflect Recite Dan Review (PQ4R) Untuk Meningkatkan Hasil Belajar. Puteri Hijau: Jurnal $\begin{array}{lll}\text { Pendidikan } & \text { Sejarah, } & 2(1),\end{array}$ https://doi.org/10.24114/ph.v2i1.9084

Sisworo, \& Dkk. (2016). Analisis Kemampuan Berpikir Kritis. Prosiding Konferensi Nasional Penelitian Matematika Dan Pembelajarannya, 3(Knpmp I), 580590. https://doi.org/10.23971/eds.v5i2.732

Sugiyono. (2016). Metode Penelitian Kuantitatif, Kualitatif dan Kombinasi (Mixed Methods). Bandung: Alfabeta, 2016.
10.1016/J.Datak.2004.11.010

Wahyuni, A. N. (2012). Pengembangan Media Komik Bergambar Materi Sistem Saraf Untuk Pembelajaran Yang Menggunakan Stratergi PQ4R. Journal of Innovative Science Education, 1(2), 102-109.

Zarnuji, A. (2017). Implementasi Metode Preview, Question, Read, Reflect, Recite \& Review dalam Menghafal Hadits pada Mata Kuliah Hadits Tarbawi. Tapis: Jurnal Penelitian Ilmiah, 1(01), 134. https://doi.org/10.32332/tapis.v1i01.732 